\title{
THE IMPLEMENTATION OF BUTON CULTURAL VALUES IN VALUE EDUCATION PLANNING IN BAUBAU REGION OF SOUTHEAST SULAWESI
}

\author{
Nanik Hindaryatiningsih \\ Universitas Haluoleo Kendari \\ nani_unhalu@yahoo.co.id
}

\begin{abstract}
The study aimed at finding out the implementation of Buton cultural value into value education planning. This study employed qualitative approach by ethnographic method conducted at SMAN 2 Baubau, south east Sulawesi in 2012. For data collection, in-depth interview techniques, documentation review, and participant observation consisting descriptive, focused and selected observation were used. The observation focused on cultural events and interactive behavioral informants. The informants comprised of principal, teachers, staff, school committee, pupils, parents, community leaders and traditional leaders. For data analysis, spradley technique consisting of domain analysis, taxonomy, componential and theme analysis was used. The findings showed that 1) core values in "gau and pombala" culture in Buton community consisted of cooperative, democratic and ethic value; 2) Buton's cultural values of "gau and pombala' were practiced in educational value planning at school.
\end{abstract}

Keywords: democratic, cooperative, ethic, value implementation, educational planning.

Juvenile delinquency are often covered on the national media. In relation to students, dishonesty, cheating, impoliteness and the lack of respect given to teachers are some of the behaviours found in school. Misconducts such as these are found throughout the country. It indicates that education has yet to succeed in improving students' behaviour. It is arguable that despite the religious and moral teachings in schools, these misconducts continue to persist. Moreover, the ever increasing improvement of technological access to the media and the global world may have negative influence on the students' behaviour by adopting values and habits which do not follow the traditional culture and are not socially acceptable in their community. Rahim (2011: 24-25) argue that traditional values are easily threatened as a consequence of the improvement in information and technology These negative development may occur due to a value shift, in either religious values, customs or cultural values.

Indonesia is known to be a civilized nation, deriving positive values from the cultural wisdom of its diverse ethnic backgrounds. For instance, Buton community in Southeast Sulawesi has known to practice their value system and life philosophy referred to as bhinci-bhinciki kuli. This traditional value teaches of the four principles, including love, mutual respect, mutual fear, and mutual care, that is summed up as sara pataanguna (Turi, 2007: 139). Rahyono (2009:7) stated that cultural wisdom itself is a community product that may be applied as a means of education. Colquitt et al. (2009: 292) said that, "cultural values defined as shared beliefs about desirable end states or modes of conduct in a given culture". Thus, the Buton cultural values could be integrated into the schools in Buton to improve students' behavior. 
To benefit the society, particularly the younger generation, the core cultural values could be made more relevant to the current condition. One way is through integrating these values into the formal education in school. Educating students of these values through guidance and teaching enable students to understand, to be aware and experience them to be able to apply them in everyday life (Mulyana, 2004: 119). Educating students of these value is an effort to internalize noble values to the students which could improve their moral quality and character.

Educating students of these values is nothing new in the education world. However, this approach can be applied throughout all the learning processes, such as through extracurricular program, education on school culture or through integrating these values in some general subjects. Dewantara (1967: 80) sugggested that learning the ways towards national unity, to strengthen the nation's culture, and to embrace the spirit of the nation should be taught in the list of general instruction. The learning materials could be taken from religious values, customs, history, arts and other subjects related to civilization. The value education program must be relevant with the curriculum or subjects which raises moral values. According to Colgan (2003), character education programs must be relevant to the curriculum, there has to be some connection between morality and the curriculum.

Value education has been implemented in the formal education since curriculum of 1947 through courtesy education. In the curriculum of 2010, the implementation of character education has been internalized in all school activities. Character education focuses on basic value to build national character through developing students' basic character. Two basic values that are considered important to be taught in school are the values of respect and responsibility, while other virtues can be developed and adjusted with the conditions and needs of the respective schools (Zubaedi, 2011: 72). Zubaedi (2011: 73) also added that the development of these values are derived from how the nation view life, religious issues, culture and other values that are then formulated to be integrated into the national education. The policies of integrating values into the formal education is done in the hope that schools take part in providing guidance to all students in both cognitive and affective aspects in order to have the emotional, social, intellectual and spiritual intelligence needed.

Despite the government's effort in producing the 2010 education policy to promote value education through character education, its implementation fall far from expectation. Most people even presume that value education failed to be implemented in schools. They are able to conclude this due to the increasing number of juvenile delinquency cases in Indonesia today. Several issues are thought to contribute to the failure of the program. First is the issue of the imbalance of programs ran by school where the program is focused more on intellectual development or aspects of cognition and ignored promoting the development of students' attitudes and behavior. Academic achievement by garnering knowledge is thought to be more important, and this consequently ignored the aspect of building students' character. This goes against the belief that teaching values should be as important as teaching knowledge. Gray proposed that "teaching character should be just as important as teaching academics. Society will continue to be in a state of chaos until character is taught at schools again. In this way education can be used as a way to Significantly Decrease overtaking society from moral decay. Teaching is a reflection of the morality of society, so education is inevitably caught up in the moral 
debate” (2009: 1). Value education seems to be a necessity at school because education can minimize poor behavior and reduce the negative consequences which may affect students. It is a given that students who are well educated will be well behave in schools and their community.

Based on the noble goal of value education and the problems presented earlier, there is a necessity to design and formulate personal development program and extra curricular activities which integrate value education in planning school programs. This involves compiling the program appropriately and instilling the values to the program planners as proposed by Zainal and Suzak (2011: 32). Instilling good values is an essential task of the principal of the program planning.

The values to be integrated need to be in accordance to the Indonesian culture, both on its cultural and spiritual values. Foreign values that could be integrated should be in accordance to the cultural roots of Indonesia. Samani and Hariyanto (2011) stated that the cultural values to be instilled can be cultivated from a variety of traditions and culture in Indonesia, from existing religious teaching as well as leadership practices in Indonesia.

Previous researches on local cultural values include Ekosusilo's study (2003). found that the universal elements of a culture shaped the cultural value system in three primary schools in Malang. Turi's study (2006) found that local culture affeted the implementation of school-based management, including principal leadership, decision-making patterns, school managemeng, and school discipline culture. Viadero (2007) concluded that studies on character education programs resulted positively on academic and social development of students. These studies shows that values of local culture have profound positive influence in shaping a school's culture.

In line with the above findings, it is necessary to have a synergy between parents, communities and schools. Schools can infove parents, communities, students, and its employees to formulate a plan activity of school in local programs. Banghart and Trull (1973: 97) argue that "educational planning must be participatory planning that provides socially integrated educational experiences. It is necessary to involve all personnels within the schools and the community for innovative school planning that would be responsive in solving existing problems. Planning is necessary for an educational institution in guaranteeing its sustainability.

It is imperative to apply positive local cultural values in value education activities. These values could be used to build collaboration at schools through planned policies and programs. Principals could adopt local cultural values in managing the school which could serve as guidance on good behavior for school management and students.

Based on the above explanation, the goal of this research is to examine: (1) the core values of Buton culture "gau and pombala" and (2) the application of Buton cultural values "gau and pombala" in the preparation of value education planning at SMAN 2 Baubau.

\section{METHOD}

This research uses a qualitative approach, particularly using the ethnographic method which aim to explore the cultural events and the interaction of observable natural behaviors. The data gathered are information pertaining to value education 
in the form of words/sentences, activities and actions of employees and students of SMAN 2 Baubau that is related to Buton's cultural values of "gau and pombala". This also includes the atmosphere of the school. Data and information were collected through in-depth interviews with informants, participant observation, and documentation.

This research follows the steps developed by Spradley (1997: 181), which include (1) to conduct comprehensive observation to get an overview of the context of the research; (2) to analyze the initial findings and determine the focus of the study; (3) to conduct a mini-observation gain deeper understanding of the chosen focus; (4) to perform data analysis; (5) to infer the result of the research and to write up the report.

Spradley's method (1997: 139-262) is also used to analyze the data, including (1) domain analysis, (2) taxonomic analysis, (3) componential analysis, and (4) analysis of the theme. The examination of the validity of data used several criteria, namely: (1) validity, (2) transferability, (3) dependably, and (4) conformability.

\section{RESULTS}

There are two findings that were derived from this study. The first is the value of "gau and pombala", and the second is the application of the value into the value education planning of SMAN 2 Baubau.

The main values of the Buton culture "gau and pombala" consist of democracy, ethics, and cooperation. Democratic values can be seen in policy making process or program planning, where stakeholders contribute to the planning through discussion prior to its implementation. Gau is defined as a of deep discussion before executing imperial policies. Pombala is defined as taking into account and choosing advice from others before arriving to a decision. Thus, "gau and pombala" is the culture of deliberation and consensus. "Gau" as a way to formulate policy or argumentation planning provides an opportunity to all participants to express their opinions, ideas, and thoughts in order to find the best decision.

Ethical values can be seen in the application of "gau". All participants attending a discussion meeting must obey the rules called aso-aso that is related to the concept of oni te batanga or which literally means spoken word. Participants are requested to respect the opinion of others by not interrupting or even instructing other participants to speak. Speakers must be polite and if they disagree to an opinion, they must be able to convey their meaning without offending others. Leaders in the discussion is required to take into account all opinions or ideas from participants of a meeting, and to discuss them together.

Cooperation is defined as working together to achieve a common goal (Samani and Hariyanto, 2011: 104). The value of cooperation appears on school planning which involves team work. Each person was given an opportunity to speak up to both sultan and members of sara sultan who participate in the meeting. Group participation is beneficial in order to arrive to the best decision.

The second part of the finding is the application of "gau and pombala" value in value education planning. The cooperative value could be found in educationa process where the principal conduct planning together in a teamwork. Cooperations in the form of teamwork could be observed when designing programs by involving 
school personnel and relevant stakeholders which include school committee or parents and the community surrounding the school. Principals could guide the group to brainstorm and discuss the solution to problems faced by school. The diverse knowledge and experience of each stakeholders could contribute to providing solutions.

The democratic value of "gau and pombala" can be seen in the decisionmaking process of setting school programs which involve processes of negotiation and giving inputs. Considering that value education program is part of school program, the principal could discuss it openly and democratically with the stakeholders, including teachers, students, parents or school committee and the community. The principal could request the personnels of the school to design and formulate a program which would be presented to all stakeholders. The principal would accommodate all opinions, discuss, sort and select opinion before arriving at a decision that is considered best. The principal would decide on a plan through deliberation and consensus. This planning of school program activities would be conducted at the beginning of each academic year and is in line with the school's vision.

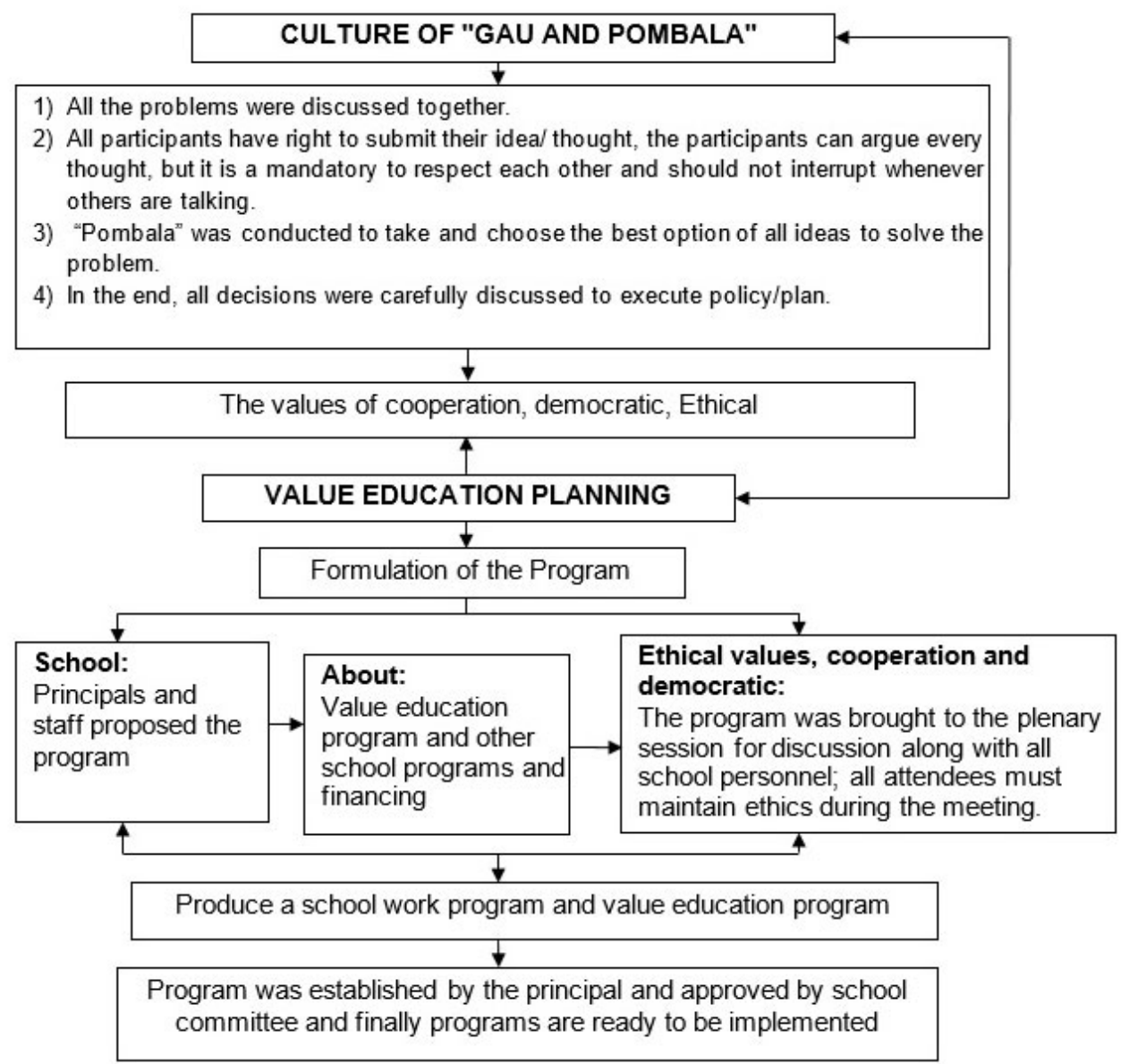

Picture 1. Chronology of cultural values "Gau and Pombala" in ducation of Value Planning at SMAN 2 Baubau 
The ethical value of "gau and pombala" is reflected in the rules which must be adhered by all participants. In discussing towards the planning of school program, each participant is obliged to respect the opinion of others and is not allowed to interrupt others when speaking. Every opinion will be discussed together and will be taken into account before arriving at the final decision. With the agreement of all participants, the principal would set value education programs among other programs which would require approval from the school committee before they are ready to be implemented. The following figure described the finding of this study: (Picture 1).

\section{DISCUSSION}

Core values in the cooperative culture of "gau and pombala" applying in the preparation of value education include (1) the value of cooperation (2) democratic value, and (3) ethic value.

Cooperation is defined as working together to achieve a common goal (Samani and Hariyanto, 2011: 104). The value of cooperation is implemented in planning value education programs which involves all relevant stakeholders. Each plan cannot be separated from the decision making process and principal's are required to make decisions quickly. The stakeholders' involvement with the planning with their knowledge, skills, and experience are beneficial to address the problems and issues faced by the school. According to Daft (2010: 228), "for people, throughout the organization to be in in decisivolved on making and have the information, skills, and freedom they need to respond immediately to problems and questions".

Cooperation established among school stakeholders is an absolute necessity in developing school programs which focused on being learner-center. The success of a school program planning is determined more by the group's willingness and sincerity in giving contribution, information and thoughts. According to Robbins (2006: 356; 2012), a teamwork generates positive synergy through coordinated effort. Their individual efforts results in a level of performance that is greater than the sum of those individual inputs. Groups interact to share information and make decisions to support the organization, in pursuant of its authority and responsibility. In this way, this type of team work provide an alternative which reduces the risk of conflict or dissatisfaction over certain decision. However, since each decision ranks high in its importance to the individuals, schools and community, it is a requirement that school personnels and the community to work together as as a cohesive team to achieve an agreed goals on school program planning, particularly on value education program planning.

Furthermore, educational planning should incorporate the participation from the community. According to Banghart and Trull (1973: 97), "educational planning must be participatory planning that provides socially integrated educational experiences".

The democratic values of "gau and pombala" is reflected in its value education programs as well as other programs that were designed and specified by deliberation and consensus. Democracy is interpreted as a way of thinking, having attitude and acting the same rights and obligations to himself and others (Zubaedi, 2011: 75). The 
democratic values in the culture of "gau and pombala" reflected at decision planning of SMAN 2 Baubau where all individuals discussed issues and argue their opinions to arrive at the best decision. All interests are accommodated in the discusion and participants can argue their opinion. Each participant has the same right and obligation. Their right is to express opinion while their obligation is to listen to others' opinion. According to Daft (2010: 230), "an important key to better decision making is to encourage a rigorous debate

A debate may arise in a democracy since people are given the opportunity to express their point of views and to listen others'. It is common to find conflict or dispute that resulted from fierce debates. However, according to Daft, "good managers recognize that constructive conflict based on divergent points of view can bring a problem into focus, clarify people's ideas, stimulate creative thinking, create a broader understanding of issues and alternatives, and improve decision quality" (Daft: 2010: 230).

The formulation of value education planning that are based on Buton cultural values by the school's stakeholders were based on their experiences (intuitive) and had undergone negotiations and compromises in order to come up with the planning that are approved by the the majority of stakeholders. According to Robbins (2006: 197), the cultural background of a decision maker influences their ability to solve problems, their ability to conduct in-depth analysis, their view in perceiving the level of importance of certain issues that are considered logical and rational, and whether the problem would be solved by autocratic manager or solved collectively by group. Their pattern of decision making process tends to emphasize in favouring to satisfy subordinates by making compromise and making decision based on their experience. Therefore it can be concluded that decisions made by using "gau and pombala" is a combined approached bounded by rationalitality and political approach.

Robbins (2006: 186-187) said that the model of bounded rationality is based on two important concepts in decision making: limitation of rationality and the desire to satisfy. Limitation of rationality refers to the limitation of human being to think rationally. The desire to satisfy refers to the idea that decision making gives more emphasis on choices to satisfy their members and to solve problems without capturing its complexity and taking into consideration other alternatives that are considered important Meanwhile, according to McGrew, political approach is a model of decision-making done collectively through a process of negotiation and bargaining and guided by the rules of organization (cited from Salusu, 2006: 67-68).

The principal of SMAN 2 Baubau applied behavioral style in making decisions. Robbins conflict (2006: 194) said that the behavior style in making decisions encourages a leader to pay a lot of attention to those in the organization, to pay attention to customer satisfaction, to take suggestions openly, and to try to avoid. According to Daft (2010: 226-227), "people with a behavioral style usually are concerned with the personal development of others and the make decisions that may help others achieve their goals.

The implementation of the ethical value of "gau and pombala" was found in the rules that were to be followed by participants in the meetings of RKS and RAPBS of SMAN 2 Baubau. Ethical values are related to moral and decency (De Vos, 2002: 4). Agreed ethical values that were to be followed are enforced by the principal. The ethical values must promote a sense of appreciation by fellow attendees towards one another. Fellow attendees to the meeting should not interrupt each other and should 
use polite words to present their views. The principal who lead the meeting should give plenty of opportunity to each of the school's component to argue, to express complaints, to contribute ideas and thoughts. A leader in the decision-making process uses the values that could be obtained since youth as the fundamental knowledge. The knowledge can be used as a guideline for a person facing a situation in which a choice must be made. According to Ivancevich et al. (2008: 392), values can be considered as guideline that can be used by a person when confronted with a situation in which a decision must be made. It is acquired early in life and is often considered to be basic and a taken-for-granted part of an individual's thoughts.

The rules that have been agreed should not be violated because it would means going against the social norms of behavior prevailing in the society. Ethics provides guidance on what should be done and what is prohibited as well as moral values that should be followed by both managers and members of an organization. In relation to the value education planning, ethics is important for ethical decision making. Ethical decision is a decision which follows ethical rules, principles, and standards, norms that have become standard in the organization or society. In making an ethical decisions, a leader must avoid violating other people's right, such as the right of each individual to speak without bias, the right to have fair treatment, and the right to have freedom of speech (Daft, 2010: 148).

This research conclude that the implementation of value education planning adopted the value of "gau and pombala" which contain educational values of democracy such as respecting people regardless of their status or position, to respect differences and to express opinion politely, as well as cooperating with others.

Teaching democracy as early as possible to students and other school personnel is very important. Integrating democratic values in the planning process of educational programs as well as other values is an implementation of the National Education Law No. 14/2003, article 3, which stated that the National Education has the function to develop skills, to shape character and to develop a dignified civilized nation aimed to improve the intelligence of the nation's population, to develop the students' potential to be a human with faith and to be God-conscious, noble, healty, knowledgable, skilled, creative, independent, as well as being a democratic and responsible citizen.

\section{CONCLUSION}

The study found that the Buton cultural value of "gau and pombala" consists of the three values of democracy, cooperation and ethics. These three value have been implemented in the planning for value education. Integrating cultural value into the educational program planning is no easy task but is very crucial in facing the challenges of the nation's character building. Education through schools must build students' morality by teaching them of wisdom. Educational programs should be able to strengthen the understanding of ethical concepts to promote the moral development of students. 


\section{REFERENCES}

Aqib, Zainal dan Sujak. (2011). Panduan dan Aplikasi Pendidikan Karakter untuk SD/MI, SMP/MTs, SMA/MA, SMK/MAK. Bandung: Yrama Widya.

Banghart, F.W. dan A.Trull. (1973). Educational Planning. New York: MacMillan Publishing Company.

Colquitt, Jason A., Jeffery A. Lepine, and Michael J. Wesson. (2009). Organizational Behavior, Improving Performance and Commitment in the Workplace. New York: McGrawHill.

Daft, Richard L. (2010). New Era of Management. South-Western: Cengange Learning.

Dewantara, Ki Hajar. (1967). Kebudayaan. Yogyakarta: Taman Siswa.

Ekosusilo, Madyo. (2003). Sekolah Unggul Berbasis Nilai (Studi Multikasus di SD/MA Negeri 1, SMA Regia Pacis, dan SMA Al Islam 01 Surakarta). Disertasi. Universitas Negeri Malang.

Ivancevich, Konopaske, Matteson. (2008). Organizational Behavior and Management. New York: McGraw-Hill.

Mulyana, Rohmat. (2004). Mengartikulasikan Pendidikan Nilai. Bandung: Alfabeta.

Rahyono, F.X. (2009). Kearifan Budaya dalam Kata. Jakarta: Wedatamawidyasastra.

Robbins, Stephen P. (2006). Perilaku Organisasi. Terjemahan Benyamin Molan. Jakarta: PT. Indeks.

Robbins, Stephen P. dan Mary Cuolter. (2012). Management. New Jersey: Pearson Education, Inc.

Spradley, James P. (1980). Participant Observation. New York: Holt, Rinehart and Winston.

, (1997). Metode Etnografi. Terjemahan Misbah Zulfa Elizabeth.Yogyakarta: PT Tiara Wacana.

Samani, Muchlas dan Hariyanto. (2011). Konsep dan Model Pendidikan Karakter. Bandung: PT. Remaja Rosdakarya.

Salusu, J. (2006). Pengambilan Keputusan Strategik untuk Organisasi Publik dan Nonprofit. Jakarta: Grasindo. 
Turi, La Ode. (2006). Budaya Lokal Dalam Pelaksanaan Manajemen Berbasis Sekolah di SMPN 7 Baubau Sulawesi Tenggara. Disertasi. Universitas Negeri Jakarta.

(2007). Esensi Kepemimpinan Bhinci-Bhinciki Kuli Suatu Tinjauan Budaya Kepemimpinan Lokal Nusantara. Kendari: Khazanah Nusantara.

Vos, H. De. (2002). Pengantar Etika. Yogya: Tiara Wacana.

Zubaedi. (2011). Desain Pendidikan Karakter Konsepsi dan Aplikasinya dalam Lembaga Pendidikan. Jakarta: Kencana. 